\title{
PERAN GURU PENDIDIKAN KEWARGANEGARAAN DALAM MENINGKATKAN DISIPLIN SISWA SMA NEGERI 1 KULISUSU KABUPATEN BUTON UTARA PROVINSI SULAWESI TENGGARA
}

\author{
Izan Nafrin, N. F. Kaunang, Y. D. A. Santie \\ Jurusan PPKn FIS Unima \\ Email:izannafrin@gmail.com
}

\begin{abstract}
ABSTRAK
Permasalahan dalam penelitian ini tentang" Bagaimana Peran Guru PKn Dalam Meningkatkan Disiplin Siswa SMA Negeri 1 Kulisusu Kab. Buton Utara Provinsi Sulawesi Tenggara?". Sedangkan tujuan dari penelitian ini adalah untuk mengetahui Peran Guru PKn Dalam Meningkatkan Disiplin Siswa SMA Negeri 1 Kulisusu. Metode yang digunakan dalam penelitian ini adalah metode penelitian pendekatan kualitatif deskriptif. Penelitian desktiptif kualitatif merupakan penelitian yang termasuk jenis penelitian kualitatif. penelitian ini diharapkan mampu memberikan gambaran atau menceritakan tentang peran guru dalam meningkatkan disiplin siswa. Berdasarkan hasil penelitian dan pembahasan pada bab-bab sebelumnya, maka dapat disimpulkan, sebagai seorang pendidik guru telah berusaha menjalankan perannya dengan baik yaitu menjadi panutan bagi para siswanya. Cara berperilaku yang baik dan berbicara sopan dengan para siswa menjadikan sosok seorang guru yang patut diteladani oleh para siswa. Pemberian motivasi dan nasehat yang baik kepada siswa akan dapat menjadikan siswa memilki karakter yang baik dalam hal ini karakter disiplin. Guru juga harus selalu memberikan contoh perilaku yang baik kepada siswa.
\end{abstract}

\section{Kata Kunci : Peran Guru, Disiplin Siswa}

\section{PENDAHULUAN}

Pendidikan sering diartikan sebagai usaha manusia untuk membina kepribadiaanya sesuai dengan nilai-nilai di dalam masyarakat dan kebudayaan. Dalam perkembangannya, istilah pendidikan berarti bimbingan atau pertolongan yang diberikan dengan sengaja oleh orang dewasa agar ia menjadi dewasa (Hasbullah, 2013:1).

Berdasarkan undang-undang sistem pendidikan nasional (UU sisdiknas) Nomor 20 Tahun 2003, Pendidikan adalah sebagai usaha sadar dan terencana untuk mewujudkan suasana belajar dan proses pembelajaran untuk peserta didik secara aktif mengembangkan potensi dirinya untuk memiliki kekuatan spiritual keagamaan, pengendalian diri, kepribadian, kecerdasan, akhlak mulia, serta keterampilan yang diperlukan dirinya, masyarakat, Bangsa Dan Negara.a Pengertian Pendidikan dapat diartikan sebagai usaha sadar dan sistematis untuk mencapai taraf hidup atau untuk kemajuan lebih baik. Secara sederhana, Pengertian pendidikan adalah proses pembelajaran bagi peserta didik untuk dapat mengerti, paham, dan membuat manusia lebih kritis dalam berpikir.

Sehubungan dengan itu, Tujuan Pendidikan Nasional adalah mencerdaskan kehidupan bangsa dan mengembangkan manusia Indonesia seutuhnya, yaitu manusia yang beriman dan bertaqwa terhadap Tuhan Yang Maha Esa dan berbudi pekerti luhur, memiliki pengetahuan dan keterampilan, kesehatan jasmani dan rohani, kepribadian yang mantap dan mandiri serta rasa tanggung jawab kemasyarakatan dan kebangsaan. Dengan adanya pendidikan, maka akan timbul dalam diri seseorang untuk berlomba-lomba dan memotivasi diri kita untuk lebih baik dalam segala aspek kehidupan. Pendidikan merupakan 
salah satu syarat untuk lebih memajukan pemerintah ini, maka usahakan pendidikan mulai dari tingkat SD sampai pendidikan di tingkat Universitas.

Pada intinya pendidikan itu bertujuan untuk membentuk karakter seseorang yang beriman dan bertakwa kepada Tuhan Yang Maha Esa. Akan tetapi disini pendidikan hanya menekankan pada intelektual saja, dengan bukti bahwa adanya Ujian Nasional sebagai tolak ukur keberhasilan pendidikan tanpa melihat proses pembentukan karakter dan budi pekerti anak.

Selain itu, Tujuan Pendidikan Nasional dalam Undang-Undang No. 20, Tahun 2003 Jabaran UUD 1945 tentang pendidikan dituangkan dalam Undang-Undang No. 20 Tahun 2003. Pasal 3 menyebutkan, "Pendidikan nasional berfungsi mengembangkan kemampuan dan membentuk watak serta peradaban bangsa yang bermartabat dalam rangka mencerdaskan kehidupan bangsa, bertujuan untuk berkembangnya potensi peserta didik agar menjadi manusia yang beriman dan bertakwa kepada Tuhan Yang Maha Esa, berakhlak mulia, sehat, berilmu, cakap, kreatif, mandiri, dan menjadi warga negara yang demokratis serta bertanggung jawab." Untuk mewujudkan tujuan pendidikan seperti yang telah di jelaskan di atas maka diperlukan sekolah.

Sekolah merupakan sebuah lembaga pendidikan yang bersifat formal yang didirikan oleh negara ataupun swasta yang di rancang untuk mengajari, mengelola dan mendidik peserta didik melalui bimbingan yang diberikan oleh tenaga pendidik. Untuk menjadi sebuah sekolah, ada beberapa sarana dan prasarana yang harus dipenuhi, seperti ruang belajar, perpustakaan, kantor dan lain sebagainya.

Dalam Kamus Besar Bahasa Indonesia sekolah sebagai sebuah lembaga atau bangunan yang digunakan untuk kegiatan belajar mengajar serta menjadi tempat memberi dan menerima pelajaran sesuai dengan tingkatannya (sekolah dasar, sekolah lanjutan, dan sekolah tinggi). Sekolah menjadi tempat dididiknya anak- anak dengan maksud mengajarkan mereka mampu menjadi manusia yang berguna bagi kemajuan bangsa.

Salah satu cara untuk mewujudkan pendidikan nasional yang berdasarkan pada
Pancasila dan Undang-Undang Dasar Negara Republik Indonesia ini yaitu dengan adanya Pendidikan Kewarganegaraan yang menjadi pelajaran wajib dan harus ada di semua jenjang pendidikan, mulai dari Sekolah Dasar (SD), SMP, SMA, bahkan hingga Perguruan Tinggi. Pendidikan Kewarganegaraan ini bertujuan untuk menyiapkan siswa dalam menghadapi kehidupan bermasyarakat, karena dengan pendidikan Kewarganegaraan siswa di ajarkan untuk kritis dan mampu memecahkan masalah yang terjadi dalam masyarakat dengan baik dan cerdas, sebagai mana yang telah diungkapkan oleh Komalasari ( 2007 : 12 ) yang menyatakan bahwa :

"melalui Pendidikan Pancasila, setiap warganegara Indonesia diharapkan

memiliki kompetensi untuk memahami, menganalisis dan menjawab

masalah-masalah yang dihadapi bangsa Indonesia secara berkesinambungan dan konsisten dengan cita-cita dan tujuan nasional."

Pendidikan kewarganeraaan adalah suatu upaya sadar dan terencana mencerdaskan warga negara (khususnya generasi muda). Caranya dengan menumbuhkan jati diri dan moral bangsa agar mampu berpartisipasi aktif dalam pembelaan negara. Pendidikan kewarganegaraan mengajarkan kepada peserta didik tentang nilai, norma dan moral. Dengan mengamalkan nilai, norma dan moral tersebut maka akan tercipta karakter disiplin dalam diri siswa. Dengan disiplin inilah proses pendidikan yang berlangsung disekolah akan berlangsung dengan baik, karena siswa tidak melakukan pelanggaran aturan aturan sekolah.

Disiplin adalah sikap mental seseorang yang mengandung kerelaan mematuhi, ketentuan, peraturan, dan norma yang berlaku dalam menunaikan tugas dan tanggung jawab. Tanggung jawab, baik yang berhubungan dengan waktu maupun terhadap kewajiban dan hak. Pengertian lain tentang disiplin diungkapkan oleh Siswanto (2001) memandang bahwa disiplin adalah suatu sikap menghormati, menghargai, patuh, dan taat terhadap peraturanperaturan yang berlaku, baik yang tertulis maupun tidak tertulis serta sanggup menjalankannya dan tidak mengelak untuk menerima sanksi-sanksinya apabila ia melanggar 
tugas dan wewenang yang diberikan kepadanya. Terbentuknya disiplin sebagai tingkah laku yang berpola dan teratur menurut Dolet Unaradjan (2003 : 28-31) dipengaruhi oleh : (1). Keadaan Lingkungan Keluarga, (2). Keadaan sekolah, (3). Keadaan Masyarakat

Menurut Ekosiswoyo dan Rachman (2000), faktor-faktor yang mempengaruhi disiplin, antara lain: (1). Dari sekolah: (a). Tipe kepemimpinan guru atau sekolah yang otoriter yang senantiasa mendiktekan kehendaknya tanpa memperhatikan kedaulatan siswa. Perbuatan seperti itu mengakibatkan siswa menjadi berpura-pura patuh, apatis atau sebaliknya. Hal itu akan menjadikan siswa agresif, yaitu ingin berontak terhadap kekangan dan perlakuan yang tidak manusiawi yang mereka terima. (b). Guru yang membiarkan siswa berbuat salah, lebih mementingkan mata pelajaran dari pada siswanya. (c). Lingkungan sekolah seperti: harihari pertama dan hari-hari akhir sekolah (akan libur atau sesudah libur), pergantian pelajaran, pergantian guru, jadwal yang kaku atau jadwal aktivitas sekolah yang kurang cermat, suasana yang gaduh, dll. (2). Dari keluarga, contohnya : (a). Lingkungan rumah atau keluarga, seperti kurang perhatian, ketidak teraturan, pertengkaran, masa bodoh, tekanan dan sibuk urusannya masing-masing. (a). Lingkungan atau situasi tempat tinggal, seperti lingkungan kriminal, lingkungan bising dan lingkungan minuman keras.

Berdasarkan observasi awal di temukan bahwa di SMAN 1 Kulisusu Kabupaten Buton Utara masih di temukan bahwa disiplin siswa sangat rendah, baik disiplin dalam menaati aturan, disiplin dalam belajar maupun disiplin waktu. Hal tersebut dikarenakan minimnya guru PKn yang mana di SMAN 1 Kulisusu hanya terdapat satu guru PKn saja. Sehingga tidak mampu mengontrol kedisiplinan siswa yang sekian banyak mulai dari kelas 10-12. Karena kurangnya kontrol dari guru PKn membuat para siswa acuh tak acuh terhadap kedisiplinan. Pada hal disiplin sangat diharapkan untuk menunjang prestasi siswa. Tetapi kenyataannya siswa SMAN 1 Kulisusu masih terdapat siswa yang memiliki karakter tidak baik dalam hal ini karakter disiplin. Karena kuranngya disiplin ini akibatnya mereka selalu melanggar aturan sekolah seperti terlambat datang sekolah, tidak memakai atribut sekolah, pulang belum pada waktunya, bahkan tidak mengikuti pelajaran dengan baik. Pada saat proses kegiatan belajar mengajar mata pelajaran PKn siswa sering keluar masuk kelas, kurang memperhatikan penjelasan dari guru, dan malas untuk mencacat, mereka cenderung bermain dengan teman sebangkunya. Kuranngya disiplin pada siswa dikarenakan perhatian dan didikan orang tua kepada anaknya sangat minim, hal itu membuat siswa menjadi malas untuk ke sekolah tepat waktu. Jika masalah disiplin ini di biarkan terus menerus maka akan menjadi kebiasaan buruk siswa kedepannya. Dan dampak panjangnya akan berakibat pada bangsa ini yang mana Bangsa Indonesia akan memiliki warga negara yang tidak disiplin dan selalu melanggar norma atau aturan serta hukum yang berlaku.

Berdasarkan latar belakang masalah diatas maka peneliti tertarik untuk melakakukan penelitian tentang " Peran Guru PKn Dalam Meningkatkan disiplin Siswa SMAN 1 KULISUSU" . Peneliti tertarik untuk meneliti masalah tersebut dikarenakan disiplin merupakan hal yang sangat penting dalam kehidupan berbangsa bahkan bernegara.

Berdasarkan latar belakang masalah, identifikasi masalah, dan pembatasan masalah yang telah di kemukakkan di atas, maka dalam penelitian ini dapat di rumuskan masalah: "Bagaimanakah Peran Guru PKn dalam Meningkatkan disiplin Siswa SMAN 1 Kulisusu Kabupaten Buton Utara Provinsi Sulawesi Tenggara"

\section{KAJIAN TEORI \\ Konsep Peran Guru}

Istilah peran dalam "Kamus Besar Bahasa Indonesia" mempunyai arti pemain sandiwara (film), perangkat tingkah yang diharapkan dimiliki oleh orang yang berkedudukan di masyarakat.

Selanjutnya peran menurut Soerjono Soekanto (2002:243), yaitu peran merupakan aspek dinamis kedudukan (status), apabila seseorang melaksanakan hak dan kewajibannya sesuai dengan kedudukannya, maka ia menjalankan suatu peranan. Kemudian bertolak dari pengertian peran di atas menurut penulis, 
yang dimaksud dengan peran adalah suatu tugas atau kewajiban yang harus dilakukan oleh seseorang sesuai dengan aturan yang telah di tentukan

Dari beberapa pengertian peran di atas,maka peran yang diamaksud dalam penelitian ini adalah suatu sikap atau perilaku yang diharapkan oleh banyak orang atau sekelompok orang terhadap seseorang yang memiliki status atau kedudukan tertentu.

\section{Pengertian Guru}

menurut Slameto, 2003: 97 Guru merupakan seseorang yang mempunyai tugas mulia untuk mendorong, membimbing dan memberi fasilitas belajar bagi siswa untuk mencapai tujuan. Guru mempunyai tanggung jawab untuk melihat segala sesuatu yang terjadi dalam kelas untuk membantu proses perkembangan siswa. Penyampaian materi pelajaran hanyalah merupakan salah satu dari berbagai kegiatan dalam belajar sebagai suatu proses yang dinamis dalam segala fase dan proses perkembangan siswa (Slameto, 2003: 97).

Selanjutnya Menurut Noor Jamaluddin (1978:1) Guru adalah pendidik, yaitu orang dewasa yang bertanggung jawab memberi bimbingan atau bantuan kepada anak didik dalam perkembangan jasmani dan rohaninya agar mencapai kedewasaannya, mampu berdiri sendiri dapat melaksanakan tugasnya sebagai makhluk Allah khalifah di muka bumi, sebagai makhluk sosial dan individu yang sanggup berdiri sendiri (Noor Jamaluddin 1978: 1).

Berdasarkan pendapat diatas, maka Guru yang di maksud dalam penelitian ini adalah orang yang pekerjaannya, mata pencahariannya, dan profesinya mengajar sehingga menjadikan peserta didik menjadi manusia yang memiliki karakter-karakter yang baik.

\section{Kompetensi Guru}

Berdasarkan Peraturan Pemerintah Nomor 19 Tahun 2005 tentang Standar Nasional Pendidikan, guru harus memiliki kompetensi pedagogik, kepribadian, profesional, dan sosial (Depdiknas, 2005:24):

1. Kompetensi pedagogik

2. Kompetensi kepribadian

3. Kompetensi profesional

\section{Kompetensi sosial berkenaan}

\section{Peran dan Fungsi Guru}

Para pakar pendidikan di Barat telah melakukan penelitian tentang peran guru yang harus dilakoni. Peran guru yang beragam telah diidentifikasi dan dikaji oleh Pullias dan Young (1988), Manan (1990) serta Yelon dan Weinstein (1997).

Adapun peran-peran tersebut adalah sebagai berikut:

1) Guru Sebagai Pendidik

2) Guru Sebagai Pengajar

3) Guru Sebagai Pembimbing

4) Guru Sebagai Pengelola Pembelajaran

5) Guru Sebagai Model dan Teladan

6) Guru sebagai administrator

7) Guru Sebagai Penasehat

8) Guru Sebagai Pembaharu (Inovator)

9) Guru Sebagai Pendorong Kreatifitas

10) Guru Sebagai Emansipator

11) Guru Sebagai Evaluator

12) Guru Sebagai Kulminator

\section{Konsep Pendidikan Kewarganegaraan}

Menurut Kerr dalam Winataputra dan Budimansyah (2007: 4), citizenship or civics education is construed broadly to encompass the preparation of young people for their roles and responsibilities as citizens and, in particular, the role of education (through schooling, teaching, and learning ) in that preparatory process. (Winataputra dan Budimansyah, 2007: 4)

Dari definisi Kerr tersebut dapat dijelaskan bahwa pendidikan kewarganegaraan dirumuskan secara luas yang mencakup proses penyiapan generasi muda untuk mengambil peran dan tanggung jawab sebagai warga negara, dan secara khusus, peran pendidikan termasuk di dalamnya persekolahan, pengajaran dan belajar, dalam proses penyiapan warga negara tersebut.

Berbeda dengan pendapat di atas pendidikan kewarganegaraan diartikan sebagai penyiapan generasi muda (siswa) untuk menjadi warga negara yang memiliki pengetahuan, kecakapan, dan nilai-nilai yang diperlukan untuk berpartisipasi aktif dalam masyarakatnya (Samsuri, 2011:28). 


\section{Konsep Disiplin}

Dalam Kamus Besar Bahasa Indonesia (1990:208), kata disiplin berarti tata tertib (disekolah kemiliteran), ketaatan (kepatuhan), pada peraturan. Dengan kata lain berdisplin adalah mematuhi atau mentaati tata tertib sedangkan mendisiplinkan berarti mengusahakan supaya mematuhi (mentaati) tata tertib ( Kamus Besar Bahasa Indonesia, 1990:210)

Menururt Sukadi (1996:150), beliau memberikan pengertian tentang disiplin diantaranya "sikap mental yang mengandung kerelaan mematuhi ketentuan, peraturan dan norma yang berlaku dalam menunaikan tugas dan tanggung jawab".

\section{METODE PENELITIAN}

Metode yang digunakan dalam penelitian ini adalah metode deskriptif kualitatif yang merupakan suatu prosedur penelitian yang mengembangkan fakta-fakta atas masalahmasalah yang diteliti serta data yang diperoleh, dikumpulkan, dianalisis, dan dijelaskan. Arikunto (2002: 107). Agar diperoleh data yang valid dalam penelitian ini perlu ditentukan teknik-teknik pengumpulan data yang sesuai. Dalam hal ini menggunakan teknik-teknik sebagai berikut: 1). Teknik observasi/ survey, 2). Teknik interview / wawancara.

Adapun data yang diperoleh peneliti dalam penelitian ini akan disajikan secara deskriptif kualitatif. Adapun yang dimaksud dengan deskriptif kualitatif menurut Miles dan Huberman ( 1884 ) dalam sugiono ( 2013:246252), mengemukakan bahwa aktivitas dalam analisis data kualitatif dilakukan secara interaktif dan berlangsung secara terus menerus sampai tuntas sehingga datanya sudah jenuh. Aktivitas dalam analisis data, yaitu: 1). Data Reduction 20). Reduksi data), 2). Data Display ( Penyajian data), 3). Conglusion Drawing / Verification.

\section{HASIL PENELITIAN DAN PEMBAHASAN}

Berdasarkan hasil penelitian yang dilakukan melalui wawancara yang dilakukan kepada guru mata pelajaran PKn dan beberapa siswa di SMAN 1 KULISUSU mengenai Peran Guru PKn Dalam Meningkatkan Disiplin Siswa, maka pada bagian ini akan di bahas berdasarkan sub fokus-sub fokus penelitian yakni peran guru PKn dan disiplin Siswa. Adapun pembahasannya sebagai berikut:

\section{Peran Guru}

Para pakar pendidikan di Barat telah melakukan penelitian tentang peran guru yang harus dilakoni. Peran guru yang beragam telah diidentifikasi dan dikaji oleh Pullias dan Young (1988), Manan (1990) serta Yelon dan Weinstein (1997). Adapun peran-peran tersebut adalah sebagai berikut :

\section{a. Guru sebagai pendidik.}

Guru adalah pendidik, yang menjadi tokoh, panutan dan identifikasi bagi para peserta didik, dan lingkungannya. Oleh karena itu, guru harus memiliki standar kualitas tertentu, yang mencakup tanggung jawab, wibawa, mandiri dan disiplin. Peran guru sebagai pendidik (nurturer) berkaitan dengan meningkatkan pertumbuhan dan perkembangan anak untuk memperoleh pengalaman-pengalaman lebih lanjut.

Berdasarkan hasil penelitian yang dilakukan, peneliti menemukan bahwa guru PPKn di SMAN 1 kulisusu telah melaksanakan tugasnya dengan baik ini dilihat dari didikan yang diberikan guru kepada siswa agar mereka selalu mentaati aturan yang berlaku disekolah.

\section{b. Guru Sebagai Pembimbing}

Guru dapat diibaratkan sebagai pembimbing perjalanan, yang berdasarkan pengetahuan dan pengalamannya bertanggung jawab atas kelancaran perjalanan itu. Di lihat dari tugas yang dilakukan oleh guru, salah satunya dengan membimbing para peserta didik ke arah yang lebih baik agar mereka lebih memaknai proses pendidikan yang sementara mereka jalani.

Berdasarkan hasil penelitian yang dilakukan, bahwa guru tersebut mampu membimbing para peserta didiknya ketika mereka tidak disiplin.

Dari penjelasan diatas, maka peneliti menyimpulkan bahwa guru PPKn di SMAN 1 kulisusu telah berusaha menjadi seorang guru yang bukan hanya mentransfer ilmu tetapi juga sebagai pembimbing bagi peserta didiknya.

\section{c. Guru Sebagai Model dan Teladan}

Guru merupakan model atau teladan bagi para peserta didik dan semua orang yang menganggap dia sebagai guru. Sebagai teladan, 
tentu saja pribadi dan apa yang dilakukan guru akan mendapat sorotan peserta didik serta orang disekitar.

Berdasarkan penelitian yang dilakukan, maka peneliti menemukan bahwa guru telah melaksanakan tugas mereka sebagai model dan teladan bagi para siswa. Ini ditunjukan dengan cara guru selalu datang lebih awal disekolah, guru juga selalu masuk kelas tepat waktu.

Dari penjelasan di atas, maka dapat disimpulkan bahwa menjadi seorang guru harus mampu memberikan contoh yang baik kepada siswa hal ini diharapkan agar supaya peserta didik memiliki panutan yang akan mengarahkan mereka menjadi lebih baik.

\section{d. Guru Sebagai Penasehat}

Guru adalah seorang penasehat bagi peserta didik juga bagi orang tua, meskipun mereka tidak memiliki latihan khusus sebagai penasehat dan dalam beberapa hal tidak dapat berharap untuk menasehati orang.

Dari hasil penelitian yang dilakukan di SMAN 1 kulisusu, bahwa guru telah melaksanakan tugasnya dengan baik, hal ini dapat dilihat dari wawancara yang dilakukan dengan guru PPKn bahwa guru di SMAN 1 kulisusu selalu memberikan nasehat-nasehat kepada siswa setiap apel pagi bahkan sebelum kegiatan belajar mengajar guru memberikan nasehat telebih dahulu.

Dari penjelasan di atas dapat disimpulkan bahwa sangatlah penting bagi seorang guru untuk memberikan nasehat-nasehat kepada siswa agar mereka menjadi siswa yang taat akan aturan dan menjadi siswa yang memiliki karakter yang baik.

\section{Disiplin Siswa}

Secara etimologis, "disiplin" berasal dari bahasa Latin, desclipina, yang menunjukkan kepada kegiatan belajar mengajar. Istilah tersebut sangat dekat dengan istilah dalam bahasa Inggris, disciple yang berarti mengikuti orang untuk belajar di bawah pengawasan seorang pemimpin. Istilah bahasa Inggris lainnya adlah discipline, yang berarti tertib, taat, atau mengendalikan tingkah laku, penguasaan diri, kendali diri.

Berdasarkan hasil penelitian yang telah dijelaskan sebelumnya bahwa masih terdapat siswa yang tidak disiplin, hal ini dapat dilihat dari perilaku siswa yang selalu terlambat datang ke sekolah, dan tidak memakai seragam dengan rapi. Selanjutnya masih ada siswa yang sering pulang sebelum waktu pulang atau bolos sekolah.

Dari uraian di atas maka dapat dikatakan bahwa peran guru PKn dalam meningkatkan disiplin siswa SMAN 1 KULISUSU, belum optimal. Oleh sebab itu, peran guru sangat dibutuhkan dalam melaksanakan fungsinya baik mendidik, membimbing serta memberikan nasehat harus terus dilakukan agar tercapai kemandirian dan mencapai tingkat perkembangan yang optimal

\section{KESIMPULAN DAN SARAN Kesimpulan}

Berdasarkan hasil penelitian dan pembahasan maka maka dapat disimpulkan bahwa :

1. Guru mata pelajaran PKn dalam meningkatkan karakter disiplin siswa di SMAN 1 KULISUSU sudah di upayakan dengan baik, hal itu terlihat dari didikan, nasehat, dan bimbingan yang diberikan kepada siswa baik pada saat apel pagi maupun pada saat seelum kegiatan belajar dimulai.

2. Di SMAN 1 KULISUSU masih terdapat sebagian kecil siswa yang bisa dikatakan belum disiplin dan masih melakukan pelanggaran tata tertib sekolah.

3. Peran yang dilakukan guru seperti mendidik, membimbing, serta menasehati siswa sangat diperlukan agar siswa-siswa yang belum disiplin bisa menjadi lebih baik lagi.

\section{Saran}

1. Untuk siswa tentunya sebagai generasi penerus bangsa agar dapat lebih menanamkan sikap disiplin dalam menaati suatu aturanaturan yang sudah ditetapkan agar supaya sebagai penerus bangsa bisa menjadi orang yang berguna baik bagi orang tua, sekolah, negara, dan masyarakat dan terlebih bagi Tuhan Yang Maha Esa

2. Untuk guru sebagai tenaga pendidik hendaknya jika akan menjadikan siswa disiplin dalam mentaati aturan terlebih dahulu mengintropeksi diri karena guru merupakan panutan sekaligus teladan yang dicontohi di sekolah. 
3. Untuk peneliti selanjutnya agar penelitian ini dapat menjadi bahan acuan untuk menyempunakan penelitian selanjutnya, agar jika terjadi kekurangan dalam skripsi ini bisa diperbaiki untuk penelitian selanjutnya guna mengetahui tentang peran guru PKn dalam meningkatkan karakter disiplin siswa apakah sudah sesuai atau belum.

\section{DAFTAR PUSTAKA}

Arikunto, Suharsimi, 2002. Metode Penelitian. Penerbit PT. Rineka Cipta : Jakarta

Arikunto, Suharsimi, 2001, Prosedur Penelitian suatu Pendekatan Praktek. Penerbit PT. Rineka Cipta: Jakarta.

Cholisin. 2000. Ikn dan PKn. Jakarta: UT (Universitas Terbuka )

Siswanto, sastrohadijiwiryo, 2003, Manajemen Tenega Kerja Indonesia, edisi 2, jakarta, PT. Bumi Aksara

Departemen Pendidikan Dan Kebudayaan. 1993, Kamus Besar Bahasa Indonesia. Jakarta: Balai Pustaka

Depdiknas. 2006. Kurikulum Tingkat Satuan Pendidikan Rumpun Mata Pelajaran Pendidikan Kewarganegaraan Sekolah Menengah Umum. Jakarta : Balitbang Depdiknas.

Dolet, Unaradjan, 2003. Manajemen Disiplin, Jakarta : PT. Gramedia Widiasarana Indonesia Ekosiswoyo dan Rachman, 2000. Bimbingan Kearah Belajar Yang Sukses. Surabaya: Aksara Baru. Ekosiswoyo, Rasdi: Rachman Maman, 2000. Manajemen kelas. Ikip Semarang : Press Semarang. Hasbullah, 2013. Dasar-Dasar Ilmu Pendidikan. Jakarta: Raja Grafinda Persada Jamaluddin, Noor, 1978. Pengertian Guru. Jakarta

Lonto lexi apeles dan pangalila theodorus, 2013. Etika kewarganegaraan. Yogyakarta : Penerbit ombak

Mulyana. 2004, ilmu komunikasi suatu pengantar. Bandung : PT remajaRosdakarya

Mulyasa. E. 2003, Kurikulum Berbasis Kompetensi;Konsep, Karateristik, dan Implementasi, (Bandung: PT Remaja Rosda Karya ).

Samsuri. 2011. Pendidikan Karakter Warga Negara. Yogyakarta : Diandra pustaka Indonesia Sukadi, 1996. Metode dan analisa penelitian mencari hubungan. Jakarta : Erlangga.

Sugiono, 2014. Metode Penelitian Pendidikan Pendekatan Kuantitatif Kualitatif dan R\&B. Bandung : Alfabeta.

Udik budi wibowo,2010. Pendidikan dari dalam:strategi alternatif pengembangan karakter. Di ambil dari jurnal dinamika pendidikan No.01/th.XVI/mei 2010.

Undang-Undang Guru dan Dosen No 14 Tahun 2005. Jakarta : Penerbit Sinar Grafika.

Winataputra, U. S dan Budimansyah, D. 2007. Civid Education, Konteks, Landasan, Bahan Ajar dan Kultur Kelas. Bandung: pogram studi kewagnanegaraan SPs UPI Bandung.

Zamroni (Tim ICCE). 2000. Paradigma Pendidikan Masa depan. Jakarta : Diglaf Pablishing.

\section{Sumber website :}

Https://karyono1993.wordpress.com/thesis/kompetensi-guru/(Di akses pada Tanggal 23 Maret 2018) Http://belajarpsikologi.com/tujuan-pendidikan-nasional/ (Di akses pada Tanggal 23 Maret 2018) Https://id.wikipedia.org/wiki/Tujuan_pendidikan (Di akses pada Tanggal 23 Maret 2018) Https://anomsblg.wordpress.com/profesi-kependidikan/peran-guru-dalam-pembelajaran/(Di akses pada Tanggal 23 Maret 2018)

Http://belajarpsikologi.com/pengertian-pendidikan-menurut-ahli/ (Di akses pada Tanggal 23 Maret 2018) 